\title{
GLUT-1 IS A PROMISING TARGET FOR ATP DEPLETION ON DIABETIC ENERGY DEFICIENCY SYNDROME
}

\author{
Bambang Purwanto, Harjanto, Elyana Asnar \\ Department of Medical Physiology, Faculty of Medicine, Airlangga University, Surabaya
}

\begin{abstract}
ABSTRAK
Diabetes adalah sindrom metabolik yang ditandai dengan ketidaksensitifan insulin, kurangnya presentasi membran GLUT-4 dan defisiensi ATP. ATP diperlukan untuk fosforilasi substrat, jalur pensinyalan, translasi protein dan kelangsungan hidup sel. Sejak GLUT-1 ditemukan sebagai transporter glukosa alternatif pada membran otot, beberapa penelitian mulai menyelidiki lebih lanjut. Penelitian ini bertujuan untuk mengetahui presentasi GLUT-1 tentang membran otot diabetes pada model tikus pada waktunya. Diabetes diperoleh dari $50 \mathrm{mg} / \mathrm{kg}$ B.W suntikan intra peritoneal streptozotocin pada tikus. Kami menemukan bahwa presentasi GLUT-1 meningkat secara signifikan pada saat tahap diabetes. Ini berkorelasi negatif dengan presentasi GLUT-4 dan mortalitas. Kemunduran eksentrik yang berjalan pada model tikus diabetes meningkatkan presentasi GLUT-1 dan kadar glukosa darah. Ini menjanjikan terapi manajemen diabetes di masa depan. (FMI 2017;53:177-179)
\end{abstract}

Kata kunci: Diabetes; transporter glukosa; defisiensi energi; eksentrik; streptozotocin

\begin{abstract}
Diabetes is a metabolic syndrome which characterized with insulin insensitivity, lack of GLUT-4 membrane presentation and ATP deficiency. ATP is needed for substrate phosphorylation, signalling pathways, protein translation and cellular survival. Since GLUT1 was discovered as alternative glucose transporter on muscle membrane, some studies started to investigate it more. This study aimed to investigate GLUT-1 presentation on diabetes muscle membrane of rat model in time. Diabetes was obtained from a 50 $m g / k g$ B.W of streptozotocin intra peritoneal injection on rat. We found that GLUT-1 presentation increased significantly in time of diabetic stages. It correlated negatively with GLUT-4 presentation and mortality. Eccentric downhill running on diabetic rat model improved GLUT-1 presentation and blood glucose level. It was promising for diabetes management therapy at the future. (FMI 2017;53:177-179)
\end{abstract}

Keywords: Diabetes; glucose transporter; energy deficiency; eccentric; streptozotocin

Correspondence: Bambang Purwanto, Department of Medical Physiology, Faculty of Medicine, Airlangga University. Jalan Prof. Moestopo No 4760131 Surabaya Indonesia. Email: bambang-purwanto@fk.unair.ac.id

\section{INTRODUCTION}

Insulin transduction is known as major signal for glucose uptake through glucose transporter presentation at plasma membrane (WHO 1999). Insulin signal transduction needs phosphorylation cascades to activate the regulator enzymes. In order to maintain the phosphorylation cascade, cell needs to maintain a lot of phosphate inorganic from ATP breaking down (Odedra et al 1982).

Lack of ATP inhibits the phosphorylation cascade so that Glut-4 failed to facilitate glucose uptake. The conditions were commonly found as a result of ATP depletion in diabetes mellitus. ATP depletion in diabetes mellitus inhibits the insulin signal transduction, glucose uptake and protein translation (Odedra et al 1982, Blodgett et al 2007). Some previous studies presumed that inappropriate response of oral anti diabetic treatment correlated with ATP depletion in diabetes mellitus (Odedra et al 1982).
ATP is recruited from metabolic glycolytic in cytosol and electron transport system in mitochondria. Main substrate of this catalytic reaction is glucose, which unfortunately failed to be transported to the intracellular in diabetes mellitus (WHO 1999). It has to be an alternative solution for Glut-4 failure and ATP depletion diabetes mellitus (Ciaraldi et al 2005).

Almost cell type has an ancient Glut-1, as primordial glucose transporter. Glucose transporter-1 was activated during ATP deficiency found in intracellular. It was constitutively presented at the plasma membrane and intensively expressed on hypoxic signalling. HIF-1 contributes as a factor to the Glut-1 expression (Blodgett et al 2007).

Previously, some studies reported an increase of Glut-1 expression and glucose uptake on exercising diabetic mouse model. Those mouse were $30 \mathrm{~cm} / \mathrm{s}$ speed of downhill running on the treadmill for 20 minutes long 
(Chambers et al 2009, Heled et al 2005) This study was aimed to investigate whether downhill running protocol increase Glut-1 expression at sarcolemma and reduce the glucose intolerance.

\section{MATERIALS AND METHODS}

\section{Animal model}

Diabetic mouse were obtained from 5 times $40 \mathrm{mg}$ streptozotocin intra peritoneal injection in 5 consecutive days. Mouse was feed and drink adequately in an individual caged. They were grouped in to exercised and unexercised group.

\section{Streptocotocin injection}

Streptozotocin was paid from Gamma Scientific Bio Lab Malang Indonesia. Streptozotocin was freshly diluted in to citric acid buffer with $\mathrm{pH} 4.5,15$ minutes before injection. Mouse was given $10 \%$ sucrose orally as drinking water at night after injection for nocturnal hypoglycaemic prevention. The diabetes induction protocol was based on Animal Model for Diabetes Consortium (AMDC) protocol.

\section{Exercise protocol}

Downhill running was performed on the treadmill, which set on negative inclination 15 degree. The velocity of treadmill running set on $30 \mathrm{~cm} / \mathrm{s}$ for 20 minutes long. Mouse was adapted gradually on the treadmill velocity for 5 minutes.

\section{Glut-1 examination}

Calf muscle of mouse was obtained and put in to $10 \%$ buffer formalin solution for a week. Muscle was blocked paraffin and sliced by microtome for immunohistochemistry process. Monoclonal mouse antibody anti Glut-1 was used to detect Glut-1 expression at sarcolemma. Glut-1 expression. We were used peroxidase method with DAB chromogenic. Positive cell was identified as brownish lining at sarcolemma, prominently different with another cells surroundings. Positive cell was measured in per cent ratio positive cells with total cells.

\section{Glucose intolerance examination}

Blood glucose was measured 2 times, once after 4 hours fasting and second is 60 minutes after glucose clamp. Blood glucose was measured using colorimetric kit with toluidine $\mathrm{O}$ reagent. Glucose clamp method is based on
AMDC protocol. Mouse was given $2 \mathrm{~g} / \mathrm{kg} \mathrm{BW}$ orally glucose through gavage.

\section{Ethical clearance}

Procedures were ethically proven with Animal Research Ethic Commission of Universitas Airlangga. Procedures were controlled under veterinary consultant.

\section{RESULTS}

Table 1. The comparison of glucose intolerance between groups

\begin{tabular}{lccc}
\hline & N & Mean & Std. Deviation \\
\hline Pre Dm & 9 & $27.9956^{\mathrm{a}}$ & 19.67915 \\
DM & 9 & $125.8889^{\mathrm{b}}$ & 51.45737 \\
DM+Ecc & 9 & $20.3122^{\mathrm{a}}$ & 31.86577 \\
\hline $\begin{array}{l}\text { a,b } \\
\text { intolerance mean }(\mathrm{p}<0.05)\end{array}$
\end{tabular}

Table 2. The comparison of mean GLUT-1 expression at sarcolemma

\begin{tabular}{cccccc}
\hline Group & N & Mean & $\begin{array}{c}\text { Std. } \\
\text { Deviation }\end{array}$ & $\begin{array}{c}\text { Std. Error } \\
\text { Mean }\end{array}$ \\
\hline Glut1 & DM & 9 & $1.8778^{\mathrm{a}}$ & .20480 & .06827 \\
DM+Ecc & 9 & $3.0444^{\mathrm{b}}$ & .67659 & .22553 \\
\hline $\begin{array}{l}\text { a,b Different superscript showed significantly different of glucose } \\
\text { intolerance mean (p<0.05) }\end{array}$
\end{tabular}

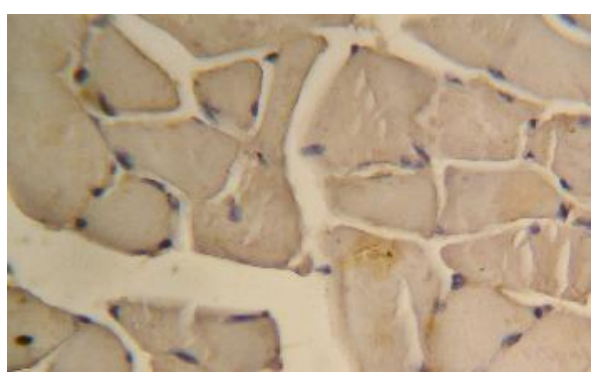

(a)

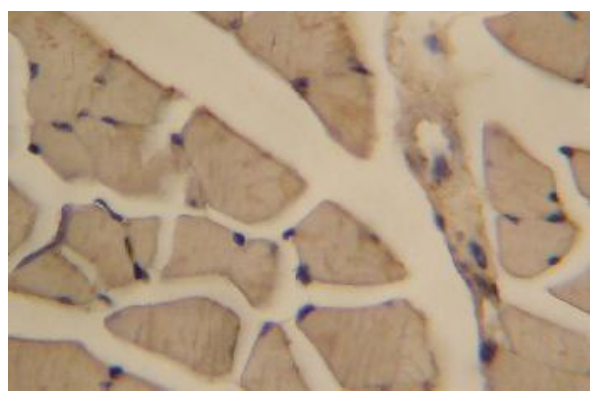

(b) 


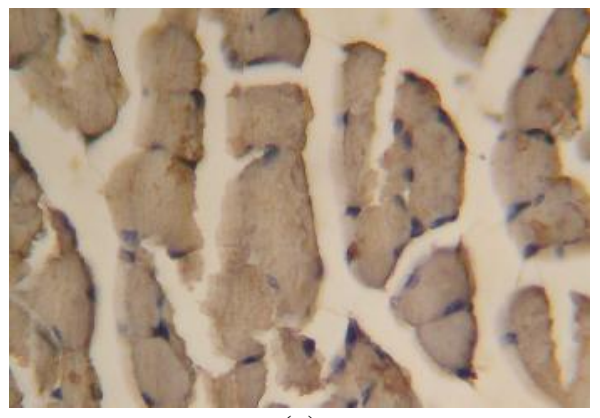

(c)

Fig. 1. The comparison of GLUT-1 expression at sarcolemma: (a) pre DM Mouse muscle, b. DM muscle, c. Exercise DM muscle.

\section{DISCUSSION}

Streptozotocin developed glucose intolerance after day 7 of injection. Streptozotocin increased both fasting and postprandial glucose significantly. Postprandial glucose failed to recoil near by fasting glucose level after 60 minutes glucose clamp. Downhill running improved it so that glucose tolerance similar to those pre DM mouse group.

Downhill running produced eccentric stretched muscle, stimulate intracellular calcium accumulation and activate hypoxia inducible factor (HIF-1) alpha. Hypoxia inducible factor (HIF-1) alpha stimulate Glut-1 protein expression and activate alternative glucose transport (Chambers et al 2009, Heled et al 2005, Barros et al 1997). Glucose transporter-1 facilitates glucose transport through sarcolemma under ATP depletion (Koivisto et al 1991, Marshall et al 1999) An increase of Glut-1 presentation helped cells to full fill energy need and activated the phosphorylation cascade for signal transduction (Koivisto et al 1991).

Calcium accumulation is needed to activate AMPK signaling on Glut- 4 translocation to sarcolemma. The translocation of Glut-4 needs some ATP to activate phosphorylation cascade. Those ATP needs were solved with Glut-1 expression improvement on exercised DM mouse. The improvement of Glut-4 expression reduced glucose intolerance after glucose clamp (Koivisto et al 1991).

\section{CONCLUSION}

Running downhill increased per cent positive cell whose presented Glut-1 at sarcolemma. The increase of Glut-1 presentation contributed to the improvement of glucose tolerance. These findings supported idea that Glut-1 as promising target for ATP improvement on diabetic mouse muscle.

\section{REFERENCES}

Blodgett et al (2007). Structural Basis of Glut1 inhibition by cytoplasmic ATP. J Gen Physiol 130, 2

Chambers et al (2009). Stretch stimulated glucose uptake in skeletal muscle is mediated by ROS \& p38 MAPK. J.Physiol 587, 13

Ciaraldi et al (2005). Skeletal muscle Glut1 transporter protein expression and basal leg glucose uptake are reduced in type 2 diabetes. JCEM 90, 352-358

Heled et al (2005). Physical exercise increases the expression of TNFa and GLUT 1 in muscle tissue of diabetes prone Psammomys obesus. Life Sciences 77, 2977-2985

Koivisto et al (1991). Differential regulation of the glut1 and glut 4 glucose transport by glucose and insulin in 16 muscle cells in culture. J of Biological Chemistry 266, 2615-2621

Marshall et al (1999). Glut1 or Glut4 transgenes in obese mice improve glucose tolerance but do not prevent insulin resistant. Am J Physiol Endocrinol Metab 276, E390-400a

Odedra et al (1982). Muscle protein synthesis in streptozotocin-diabetic rat. Biochem J. 202, 363-368

WHO (1999). Definition, diagnosis and classification of diabetes mellitus and its complication. Part1: diagnosis and classification of diabetes mellitus. Report of WHO consultation. Dept of non-communicable disease surveillance. Geneva 